\title{
Costa Rica's Marine Protected Areas: status and perspectives
}

\author{
Juan José Alvarado ${ }^{1,2}$, Jorge Cortés ${ }^{1,3}$, María Fernanda Esquivel ${ }^{4} \&$ Eva Salas $^{5}$ \\ 1. Centro de Investigación en Ciencias del Mar y Limnología (CIMAR), Universidad de Costa Rica, San Pedro, 11501- \\ 2060 San José, Costa Rica; juanalva76@yahoo.com, jorge.cortes@ucr.ac.cr \\ 2. Posgrado en Ciencias Marinas y Costeras, Universidad Autónoma de Baja California Sur, La Paz, México. \\ 3. Escuela de Biología, Universidad de Costa Rica. \\ 4. Asesores Legales del Istmo, San José, Costa Rica; mesquivel@leyescostarica.com \\ 5. Fundación MarViva, 020-651 Santa Ana; esalas.e@gmail.com
}

Received 20-I-2011. C Corrected 16-IV-2011. Accepted 18-V-2011.

\begin{abstract}
With $51100 \mathrm{~km}^{2}$ of terrestrial area and $589000 \mathrm{~km}^{2}$ of national waters, Costa Rica is considered one of the countries with the greatest biodiversity. It has approximately $3.5 \%$ of the world marine species. In the last four decades, Costa Rica has done a considerable effort to create a representative system of Protected Areas (PA), mainly terrestrial. We present an assessment of the current situation of the Marine Protected Areas (MPA) in Costa Rica, through an historical analysis, and an evaluation of their distribution, coverage and management categories. Costa Rica has 166 protected areas covering 50\% of the coastline; of these 20 are MPAs, classified as National Parks (90.6\%), National Wildlife Refuges (6.6\%), Wetlands (1.5\%), Biological Reserves (1\%), and one Absolute Natural Reserve (0.3\%). According to IUCN criteria, $93.7 \%$ correspond to category II, $5 \%$ to IV and $1.3 \%$ to I. The marine protected surface is $5296.5 \mathrm{~km}^{2}$, corresponding to $17.5 \%$ of the territorial waters and $0.9 \%$ of the Exclusive Economic Zone. The median distance between MPAs is $22.4 \mathrm{~km}$ in the Pacific and $32.9 \mathrm{~km}$ along the Caribbean. The median size is close to $54 \mathrm{~km}^{2}$. The main threats to MPAs are the lack of coordination between governmental agencies, limited economic resources, restricted patrolling and control, poor watershed management, and rampant coastal alteration. Rev. Biol. Trop. 60 (1): 129-142. Epub 2012 March 01.
\end{abstract}

Key words: management categories, Exclusive Economic Zone, marine conservation, marine protected area, size, distance.

Marine Protected Areas (MPA) are patches in the marine environment managed for the conservation of biodiversity, fisheries resources, and for research and management, generating recreational, economic, aesthetic and educational benefits (Hoyt 2005, Edgar et al. 2007). The objective of MPAs is to assure the permanence of the whole marine biodiversity spectrum, from genetic variability to populations, from species to the complete function of ecosystems, thereby providing goods and services for future generations (Lubchenco et al. 2003).

In Costa Rica, as in some other countries, the conservation efforts of terrestrial ecosystems have been greater than those directed to marine and coastal ecosystems. In 2006, Costa
Rica had a total of 166 Protected Areas (PA), representing $8404.48 \mathrm{~km}^{2}$ (22.61\%) of the continental and marine surface (including the internal waters and the Costa Rican territorial sea). The internal waters and the territorial sea (up to 12 nautical miles (nm) from the coast) covers $30308 \mathrm{~km}^{2}$ (Fig. 1). In 2006, a total of $5008.69 \mathrm{~km}^{2}$ were protected $(16.53 \%)$ (GASP 2006). However, many of those protected areas were established as extensions of terrestrial PA, based on only few criteria and baseline technical studies.

With only $51100 \mathrm{~km}^{2}$ of terrestrial surface $\left(0.03 \%\right.$ of the world) and $589000 \mathrm{~km}^{2}$ of national waters, Costa Rica is considered one of the 20 most biodiverse countries. Its 


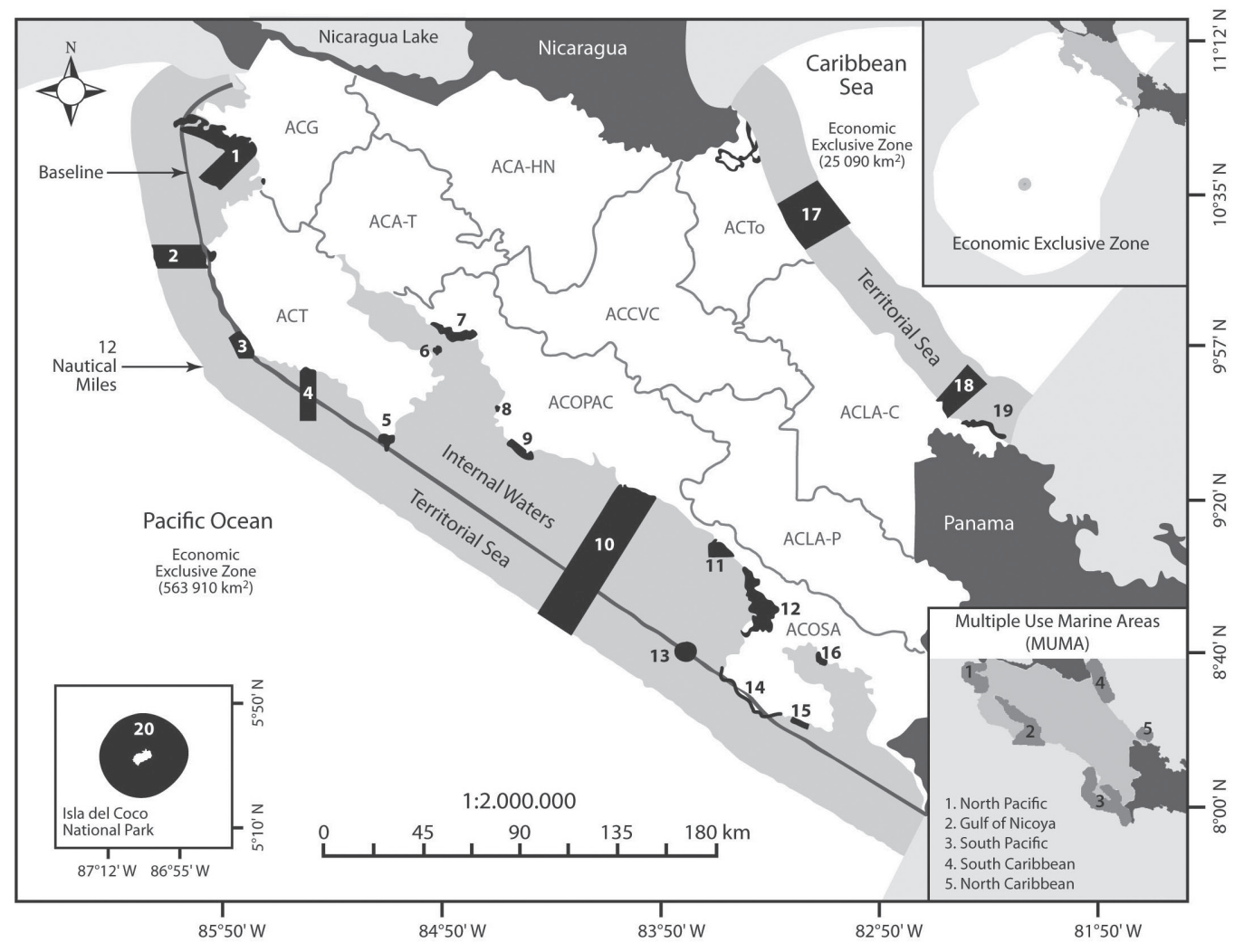

Fig. 1. Protected areas of Costa Rica, territorial waters, internal, Economic Exclusive Zone, conservation areas; Multiple Use Marine Areas (MUMA). ACG: Guanacaste Conservation Area, ACT: Tempisque Conservation Area, ACOPAC: Central Pacific Conservation Area, ACOSA: Osa Conservation Area, ACMIC: Isla del Coco Marine Conservation Area, ACTO: Tortuguero Conservation Area, ACLA-C: La Amistad-Caribe Conservation Area, ACA-T: Arenal-Tempisque Conservation Area, ACA-HN: Huetar Norte Conservation Area, ACCVC: Cordillera Volcánica Central Conservation Area. 1: Santa Rosa NP, 2: Marino Las Baulas NP, 3: Ostional WLR, 4: Camaronal WLR, 5: Cabo Blanco ANR, 6: Isla San Lucas WLR, 7: Puntarenas Estuary and mangroves W, 8: Marino Playa Blanca W, 9: Playa Hermosa WLR, 10: Manuel Antonio NP, 11: Marino Ballena NP, 12: Manglar Térraba-Sierpe W, 13: Isla del Caño BR, 14: Corcovado NP, 15: Rió Oro WLR, 16: Piedras Blancas NP, 17: Tortuguero NP, 18: Cahuita NP, 19: Gandoca-Manzanillo WLR, 20: Coco Island NP. (Source: SINAC 2007 data base).

geographical location between North and South America with coastlines along the two largest oceans, and an irregular topography that has resulted in a huge variety of microclimates, are some of the reasons for its natural richness, both in species as well as in ecosystems (Obando-Acuña 2002). So far 91000 terrestrial species have been reported for Costa Rica, representing $4.5 \%$ of the known species of the world (Obando-Acuña 2002).
Due to its tropical location surrounded by two oceans and possession of an oceanic island, Costa Rica also has a high marine richness. This particular location between two water masses (Pacific and Caribbean), which were separated about three million years ago (Coates et al. 1992), with contrasting oceanographic conditions on either side of the Panamic isthmus (D'Croz \& Robertson 1997, Jackson \& D’Croz 1997), has resulted in a flora and fauna 
with different characteristics on each side, including numerous geminate (sibling) species (Knowlton 1993, Werhtmann et al. 2009). The heterogeneous Pacific coast is $1160 \mathrm{~km}$ long and includes a series of gulfs, bays, rocky shores, beaches, and islands, among other geomorphological features; while the Caribbean coast is shorter $(212 \mathrm{~km})$ and less complex, with extensive sandy beaches in the North, and carbonate platforms with coral reef to the South (Cortés \& Jiménez 2003a, b, Cortés 2007, Cortés \& Wehrtmann 2009).

Approximately 6700 marine species have been reported from Costa Rica $3.5 \%$ of marine species reported globally), of which 90 are endemic, the majority from Coco Island (Cortés \& Wehrtmann 2009, J. Cortés 2010, pers comm.). The Pacific coast has 4700 species, while the Caribbean has approximately 2300 . However, taking into consideration the continental shelf area, the Caribbean coast has a higher diversity per $\mathrm{km}^{2}$. Compared to other countries in the region, Costa Rica is fourth in absolute number of marine species reported (Wehrtmann et al. 2009). Taking into consideration the caveat that most countries in Latin America have incomplete assessments of their marine biodiversity, Wehrtmann et al. (2009) analyzed the number of species per kilometer of coastline, placing Costa Rica in the first place, and in second place by $\mathrm{km}^{2}$ of continental shelf (Wehrtmann et al. 2009). Furthermore, Costa Rica posses a great variety of marine ecosystems, coral reefs, mangroves, mudflats, rocky shores, sandy beaches, cliffs, seagrasses, a tropical fjord (Golfo Dulce), a seasonal upwelling area, an oceanic thermal dome, an oceanic trench more than $4000 \mathrm{~m}$ deep, a submarine mountain range (Coco Ridge), many coastal islands and one oceanic island (Coco Island) (Nielsen-Muñoz \& Quesada-Alpízar 2006, Cortés 2007, Cortés \& Werhtmann 2009), and cold seeps (Bohrmann et al. 2002). For these reasons, it is important that Costa Rica sets up an efficient and representative marine protected network to conserve this richness.
The objective of this paper is to present a diagnosis of the current situation of the marine protected areas of Costa Rica, for which we used the 2007 database (the most recent) from the National System of Conservation Areas (SINAC). We present a historical analysis of the different laws or executive decrees that created the MPAs (information taken from the official governmental newspaper of the Republic of Costa Rica, "La Gaceta", and the web page from the Costa Rican Attorney General's Office, http://www.pgr.go.cr), their distribution, area, management categories, distance between MPAs (linear distance between the borders of each MPA along the coast), and an analysis of their present legal situation and threats. The goal of this review is to highlight the improvement of marine conservation over 50 years in Costa Rica, to establish a baseline for future research, located all disperse information and to allow a better understanding for a national and international audience of MPAs progress in a developing country.

\section{HISTORY}

The first protected area (PA) with a coastal zone established in Costa Rica was Cabo Blanco Absolute Nature Reserve, on the Nicoya Peninsula, in 1963. However, its marine protected area was not established until 1982. Santa Rosa National Park (NP), created in 1971, had to wait until 1987 to include a marine area, when by executive decree the Murcielago Islands and the sea up to a distance of $6 \mathrm{~km}$ from the shore were included in the protected area. During the 1970's seven PAs adjacent to marine environments were established; among those Cahuita National Park (NP), Coco Island $\mathrm{NP}$ and Caño Island Biological Reserve (BR) (Table 1, Fig. 1, 2). It is worth to notice that Coco Island and Caño Island initially did not include a marine area. The 1980's was the decade when fewer MPAs were declared (just two), while in the 1990's the total number increased to eight MPAs. During this last period, two Marine National Parks were declared, Marino Ballena and Marino Las Baulas. Also, 
TABLE 1

Marine protected areas of Costa Rica

CUADRO 1

Áreas marinas protegidas de Costa Rica

\begin{tabular}{|c|c|c|c|c|c|c|c|}
\hline Ocean & Protected area & $\begin{array}{c}\text { Conservation } \\
\text { area }\end{array}$ & $\begin{array}{l}\text { Year of } \\
\text { creation }\end{array}$ & $\begin{array}{c}\text { Marine } \\
\text { area }\left(\mathrm{km}^{2}\right)\end{array}$ & $\begin{array}{l}\text { Terrestrial } \\
\text { area }\left(\mathrm{km}^{2}\right)\end{array}$ & $\begin{array}{c}\text { IUCN } \\
\text { category }\end{array}$ & $\begin{array}{l}\text { National } \\
\text { category }^{\mathrm{a}}\end{array}$ \\
\hline Pacific & Santa Rosa & $\mathrm{ACG}$ & 1971 & 461.2 & 393.1 & II & NP \\
\hline Pacific & Marino Las Baulas & ACT & 1995 & 253.9 & 7.4 & II & NP \\
\hline Pacific & Ostional & $\mathrm{ACT}$ & 1983 & 80.9 & 4.6 & IV & NWR \\
\hline Pacific & Camaronal & $\mathrm{ACT}$ & 1994 & 160.8 & 2.3 & IV & NWR \\
\hline Pacific & Cabo Blanco & ACT & 1963 & 16.7 & 12.2 & I & ANR \\
\hline Pacific & Isla San Lucas & ACOPAC & 2001 & 4.2 & 4.3 & IV & NWR \\
\hline Pacific & $\begin{array}{l}\text { Estero Puntarenas y } \\
\text { manglares }\end{array}$ & ACOPAC & 2005 & 14.5 & 29.4 & IV & W \\
\hline Pacific & Marino Playa Blanca & ACOPAC & 1994 & 0.05 & - & IV & W \\
\hline Pacific & Playa Hermosa & ACOPAC & 1998 & 36.8 & 3.9 & IV & NWR \\
\hline Pacific & Manuel Antonio & ACOPAC & 1972 & 1243.7 & 16.6 & II & NP \\
\hline Pacific & Marino Ballena & ACOSA & 1992 & 52.2 & 3.2 & II & $\mathrm{NP}$ \\
\hline Pacific & Manglar Térraba-Sierpe & ACOSA & 1994 & 63.6 & 217.7 & IV & W \\
\hline Pacific & Isla del Caño & ACOSA & 1978 & 55.3 & 2.9 & $\mathrm{I}$ & $\mathrm{BR}$ \\
\hline Pacific & Corcovado & ACOSA & 1975 & 19.8 & 424.2 & II & NP \\
\hline Pacific & Río Oro & ACOSA & 1999 & 16.9 & 0.8 & II & NWR \\
\hline Pacific & Piedras Blancas & ACOSA & 1991 & 13.2 & 138.7 & II & NP \\
\hline Pacific & Coco Island & ACMIC & 1978 & 1994.7 & 22.6 & II & NP \\
\hline Caribbean & Tortuguero & ACTO & 1975 & 526.4 & 259.7 & II & NP \\
\hline Caribbean & Cahuita & ACLA-C & 1978 & 232.8 & 10.9 & II & NP \\
\hline Caribbean & Gandoca-Manzanillo & ACLA-C & 1985 & 48.8 & 50.7 & II & NWR \\
\hline Total & 20 & & & 5296.5 & 605.2 & & \\
\hline
\end{tabular}

Source: SINAC 2007 data base.

Fuente: base de datos del SINAC 2007.

NP: National Park, NWR: National Wildlife Refuge, ANR: Absolute Natural Reserve, W: Wetland, BR: Biological Reserve. ACG: Guanacaste Conservation Area, ACT: Tempisque Conservation Area, ACOPAC: Central Pacific Conservation Area, ACOSA: Osa Conservation Area, ACMIC: Isla del Coco Marine Conservation Area, ACTO: Tortuguero Conservation Area, ACLA-C: La Amistad-Caribe Conservation Area.

during these two decades marine areas were included in protected areas, or expanded. Since 2000, three MPAs have been declared (Table 1, Fig. 2). It is important to note that during this process many of the MPAs were intentionally declared as World Heritage Area by UNESCO (e.g., Coco Island in 1997) or RAMSAR sites.

In terms of MPA establishment, the 1980's was the decade with the highest conservation efforts; with $1985.1 \mathrm{~km}^{2}$ (37\% of the Costa Rica total MPA created, Fig. 2) created through establishment of MAPs and expansions of six PAs, including the creation of Manuel Antonio and expansion of Cabo Blanco NP, and the Gandoca-Manzanillo and Ostional NWR. Also, Coco Island NP was expanded into marine waters for the first time, to $5 \mathrm{~km}$ offshore $\left(78.5 \mathrm{~km}^{2}\right)$, as well as a second marine expansion of Caño Island, with $3 \mathrm{~km}$ around the island. One of the most interesting cases is Manuel Antonio National Park, because the size of the park increased due to 


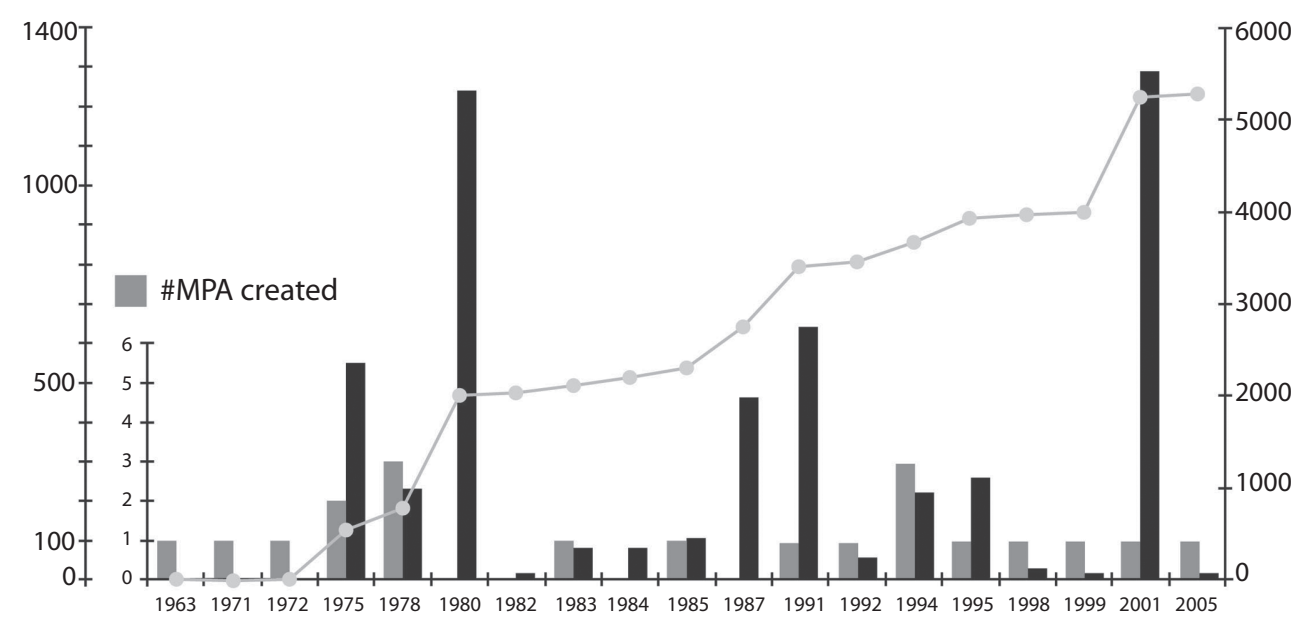

Fig. 2. Number of marine protected areas created per year (gray bars), amount of $\mathrm{km}^{2}$ of marine protected areas declared by year (black bars) and accumulated area $\left(\mathrm{km}^{2}\right)$ of marine protected areas declared over time. (Source: SINAC 2007 data base).

a re-interpretation of the establishment decree, in which the park extended its marine area 12 nautical miles from the coastal baseline. This park is located in Costa Rica's Central Pacific, in an area between two peninsulas and where an imaginary line (coastal baseline) between the peninsulas determines an area of internal waters. Now, the $12 \mathrm{~nm}$ are measured from Manuel Antonio NP to this imaginary line, rather than the real coast line in mainland (as was interpreted before), resulting in a much larger marine area (Fig. 1).

During the decades of 1990 and 2000, 1 226.4 and $1306.7 \mathrm{~km}^{2}$ respectively, were protected, compared to just $779 \mathrm{~km}^{2}$ (Fig. 2). In the case of Coco Island NP, the expansion continued in 1991 with $629 \mathrm{~km}^{2}$, until its last expansion in 2001 with $1287 \mathrm{~km}^{2}$. As with most protected areas worldwide, MPAs declared by Costa Rica were initially largely "paper parks", and some of them still are. The situation to the early 1970s, when the terrestrial National Park System was established but protection mechanisms and implementation of management plans were yet to be achieved.

\section{CURRENT SITUATION}

The National System of Conservation Areas (SINAC) is a decentralized body of the Ministry of Environment, Energy and Telecommunications (MINAET), integrated by 11 conservation areas with 166 Protected Areas (PAs) (Fig. 1), of which 59 border or contain a marine area, and three are exclusively marine protected areas (Marino Ballena Marine and Marino Las Baulas national parks and Playa Blanca National Wetland) (Mora et al. 2006).

Of those 59 PAs with marine elements, only 20 have marine areas protected. The other 39 correspond mostly with National Wildlife Refuges that protect small islands, due to their value as seabird nesting areas, but only their insular territory is protected. These 59 PAs protect more than $50 \%$ of the coastline of Costa Rica, $56 \%(119 \mathrm{~km})$ on the Caribbean coast and $51 \%(592 \mathrm{~km})$ on the Pacific side. Most of MPAs in the country are under the National Park management category (90.6\%), $6.6 \%$ in National Wildlife Refuge, $1.5 \%$ in Wetlands, $1 \%$ in Biological Reserves and one 
Absolute Nature Reserve (0.3\%). With respect to the International Union for Conservation of Nature (IUCN) management categories, 93.7\% correspond to category II (National Park), 5\% to IV (Habitat and species management area) and only $1.3 \%$ to I (Strict Natural Reserve). The marine protected extension of Costa Rica is $5296.5 \mathrm{~km}^{2}$, which represents $28.7 \%$ of the total protected surface of the country (18 $433.25 \mathrm{~km}^{2}$ ), corresponding to $17.5 \%$ of its national waters, but only $0.9 \%$ of its Exclusive Economic Zone (EEZ=589 000 $\mathrm{km}^{2}$ ).

When comparing our data with those presented by Chape et al. (2005) for Central America (17 $327 \mathrm{~km}^{2}$ total marine protected area), Costa Rica has $30.6 \%$ of the total, while at a global level $\left(1893609 \mathrm{~km}^{2}\right.$ total marine protected area) the MPA area of Costa Rica represents just $0.3 \%$. Guarderas et al. (2008) indicated that in Latin America and the Caribbean there are some 700 MPAs, covering about $300000 \mathrm{~km}^{2}$. In this sense, Costa Rica contributes with only $2.9 \%$ of the total number of MPAs and $1.8 \%$ of total area, respectively. According to PISCO (2007), all MPAs in Latin America and the Caribbean cover on average an area less than $0.1 \%$ of their EEZ, with Costa Rica above that average, but still $<1 \%$.

Costa Rican MPAs vary in size by eight orders of magnitude (Fig. 3a). The average size is $264.82 \mathrm{~km}^{2}$ including Coco Island NP and $173.78 \mathrm{~km}^{2}$ without it. However, the majority of MPAs are between $10-20 \mathrm{~km}^{2}$ (five MPAs) and $51-100 \mathrm{~km}^{2}$ (four MPAs), with a median of $53.75 \mathrm{~km}^{2}$. The largest MPA is Coco Island with $1994.69 \mathrm{~km}^{2}$ while the smallest is Marino Playa Blanca National Wetland with $0.05 \mathrm{~km}^{2}$ (Table 1). The mean distance between MPAs on the Pacific side is $22.4 \mathrm{~km}$ (excluding Coco Island NP) and $32.9 \mathrm{~km}$ on the Caribbean. Along the Pacific coast, the majority of MPAs (seven) are located between 11 and 30km from each other (Fig. 3b). Distances are smaller in the Caribbean.

Shanks et al. (2003) defined a series of criteria to establish the size and distance between MPAs according to the dispersion patterns of marine organisms. Based on those analyses they determined that a MPA should be designed to cover enough area to assure the settlement of short-range dispersion species and they must be spaced within a distance that is sufficient to allow the settlement of long-range distance propagules in adjacent MPAs. They recommend that an MPA should have at least a diameter of 4-6km to assure the settlement of short-range species, and should be spaced between 10 to $20 \mathrm{~km}$ from each other to capture long distance propagules (Shanks et al. 2003). Halpern (2003) studied the impact of MPAs with respect to size, biomass, and diversity of 89 organisms worldwide (including Manuel Antonio NP in Costa Rica). He found that MPAs have an average area of $44.1 \mathrm{~km}^{2}$, although half of the reserves were between one and $10 \mathrm{~km}^{2}$ and the median reserve size was $4 \mathrm{~km}^{2}$.

In this regard, it is important to highlight that MPAs in Costa Rica are located $22.4 \mathrm{~km}$ from each other, and have a median size close to $54 \mathrm{~km}^{2}$. When we compared these values with those presented by Halpern (2003) and proposed by Shanks et al. (2003), Costa Rica is above average with good conditions for an incipient network of MPAs that would allow exchange between populations. However, this is an assumption based on a global analysis, and does not take into account the flow between one MPA and others. Local anthropogenic, biological and physical barriers may exist, that greatly reduce such connectivity. In Latin America and the Caribbean more than $50 \%$ of MPAs are small, covering less than $6 \mathrm{~km}^{2}$ (PISCO 2007).

\section{LEGAL ISSUES}

In Costa Rica, the official definition of a MPA is given by Kelleher (1999) as follows: "any area of intertidal or subtidal terrain, together with its overlying water and associated flora and fauna, and historical and cultural features, which has been reserved by law or other effective means to protect part or all of the enclosed environment" (Art. 1 Decree $\left.\mathrm{N}^{\mathrm{o}} 35369,2009\right)$. PAs are defined by 

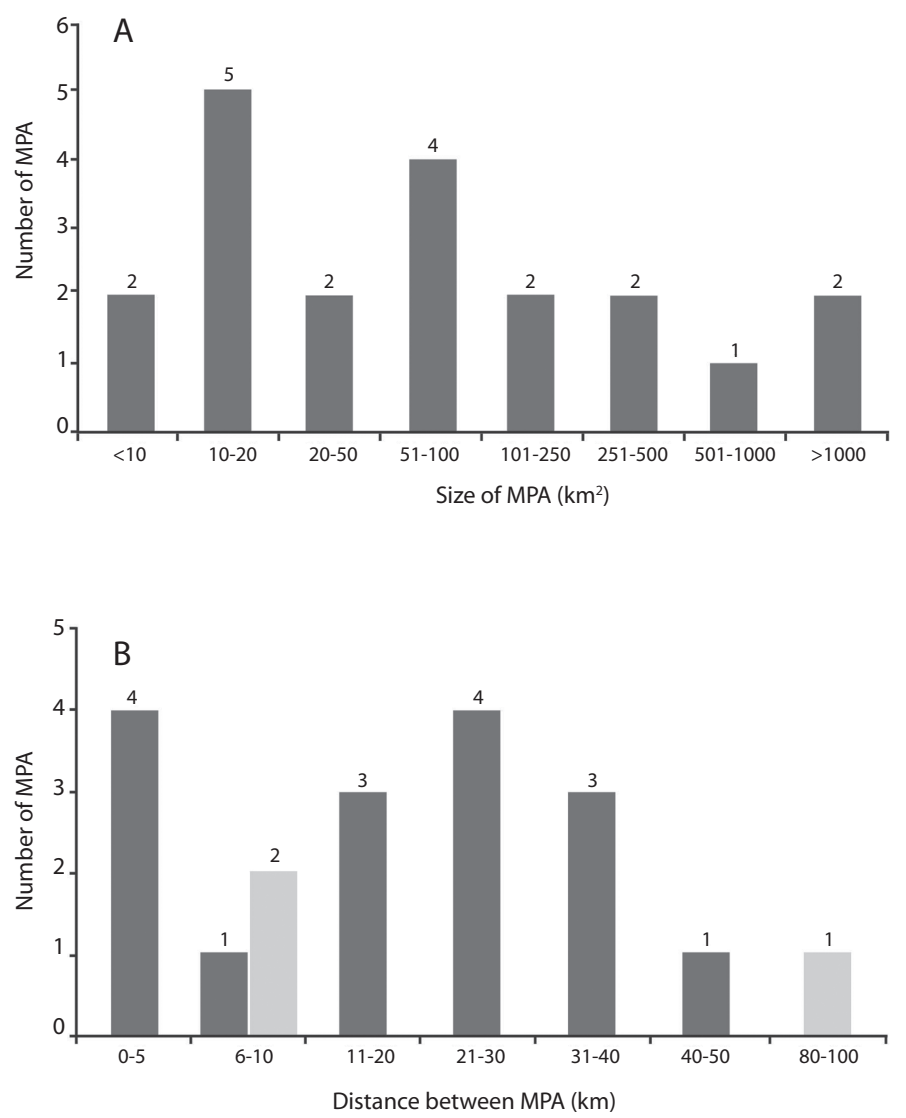

Fig. 3. A) Size $\left(\mathrm{km}^{2}\right)$ and B) distance $(\mathrm{km})$ between the marine protected areas of Costa Rica. B) Dark grey bars: 16 Pacific MPA, excluding Coco Island NP; light grey bars: 3 Caribbean MPA) (source: SINAC 2007 data base).

article 58 in Costa Rica's Biodiversity Law as "geographically delimited areas, composed by land, wetlands and portions of the ocean. They are declared as such since they represent particularly valuable ecosystems, and threatened species, areas for recovery and reproduction, and other values, and because of their cultural and historical significance. These areas will be dedicated to the conservation and protection of biodiversity, water and soils, cultural values, and ecosystems services in general".

Costa Rica has nine management categories that are used to classify PAs according to their initial objectives, following IUCN's framework (Dudley 2008). Before 2008, there were seven management categories that put high priority on terrestrial conservation, ignoring marine conservation, with exceptions of those protected areas that included marine zones under management categories like National Parks, Biological Reserves and National Wildlife Refuges (Mora et al. 2006). Each of these three categories have particular limitations, like absolute prohibitions of commercial and sport fishing, geographic restrictions $(6 \mathrm{~m}$ at low tide for wetlands), and scope of conservation and management objectives for land-based wildlife but not marine or insular species and ecosystems. Other categories are less restrictive but oriented towards terrestrial goals. 
In 2008, two additional management categories, entirely marine, were established: Marine Reserves and Marine Management Areas (Executive Decrees 34433, 35369). Marine Reserves are defined as coastal-marine and/or oceanic areas that ensure the maintenance, integrity and viability of natural ecosystems as a priority, benefiting the communities through a sustainable use of the resources, characterized by its low impact according to technical criteria. Marine Management Areas are defined as marine, coastal and/or oceanic areas where several activities take place in order to guarantee the protection and maintenance of the marine biodiversity on the long term. These two categories shall pursue to benefit the communities (dependant on the use of resources), and for education, scientific research and monitoring.

Despite that some international instruments have been ratified by Costa Rica, such as the United Nations Convention on the Law of the Sea, that provides rights and duties at State level in its national waters, until now there is no legal framework governing marine species and resources in Costa Rica's seas, lands and seabeds, that includes conservation and sustainable use perspectives rather than just a resource production perspective.

The Wildlife Law regulates continental and insular wildlife but fails to cover marine wildlife. On the other hand, Costa Rica's fisheries law, enacted in 2005, includes measures and sanctions for fish conservation. However, this law focuses mainly on the promotion and regulations of fisheries and aquacultural activities in their different phases through the final marketing and sustainable use of aquatic species, but does not address conservation.

In 1995, the Government created a category called "Marine Multiple Use Area". This category has been erroneously conceived as a management category, since in practice its purpose is to combine a marine protected area and a buffer or influence zone within a single unit. Regarding the different management types and different activities to be regulated, several authorities are responsible for regulating such activities including the Ministries of Environment, Security, and Agriculture as well as the Coast Guard.

Since Marine Multiple Use Areas have not yet been implemented, some modifications to their legal framework have been proposed with the objective to clarify objectives and scope. The real goal with creation and implementation of Marine Multiple Use Areas is to achieve coordination among the relevant authorities and stakeholders, so that adequate enforcement of regulations for each of these areas contributes to their optimal management. Unfortunately, such levels of coordination have not yet been established.

More recently, on April 2008, Costa Rica's Institute for Fisheries and Aquaculture (INCOPESCA) created a category called the "Marine Area for Responsible Fisheries" that is intended to become a zoning instrument regulating fishing activities within an area. Their creation will depend upon the biological, fisheries or socio-cultural features that require enforcement of specific regulations for guaranteeing the sustainable use of fish in the long term, as well as their use, conservation and management, with the help of local communities and institutions.

The Marine Areas for Responsible Fisheries differ from MPAs in goals and objectives. MPAs deal with a numerous aspects related to fisheries, however, they regulate several other activities that include conservation, tourism, environmental education, navigation and research. Even though creation of Marine Areas for Responsible Fisheries is very recent and only one has been formally declared to date (Palito de Chira, on the Pacific coast), many local communities are interested in promoting the creation of such areas where fishing activities occur.

\section{THREATS}

\section{Institutional threats}

The lack of coordination between governmental agencies, especially SINAC/MINAET 
and INCOPESCA, and lack of adequate mechanisms for stakeholder participation to improve governance of MPAs, are the main institutional threats. SINAC is divided into wildlife, forestry, and protected areas on the land, but there is no analogous framework for marine wildlife, fisheries and MPAs. Marine conservation is managed through SINAC, while marine wildlife work is shared between SINAC and INCOPESCA, and fisheries by INCOPESCA only.

No single MPA possesses enough personnel to implement a management plan in an ideal scenario, and only a few can execute a minimum plan. The economic situation of most MPAs is difficult, since budgets are just enough to achieve basic operation activities, such as cooking and buying gasoline, among others. Additionally, fees collected go to a government central account, from which money is reallocated between all protected areas across the country. Therefore, MPAs that attract a lot of funds, are not able to provide quality services to the users that pay for those services.

Currently, no specific training is provided for marine park rangers, and no economic incentive exits to attract people with a strong marine background. Sporadic training initiatives, which include legal aspects, marine operations, patrolling and environmental impact assessments, have occurred in specific MPAs (e.g. Coco Island and Marino Las Baulas NP). Other MPAs, such as Cahuita, Marino Ballena and Santa Rosa NP, have hired local fishermen or marine tourism operators, with experience in marine operations, but not much experience in marine management or legal issues. Most MPAs have park rangers that have been transferred from land parks to the marine area, with experience in the marine environment frequently totally lacking. Thus, park rangers and park managers need to receive adequate training in marine management and marine operations. For a number of MPAs with mainly terrestrial objectives (for example, Corcovado, Manuel Antonio and Piedras Blancas NP), efforts and funding for the marine area are rare or nonexistent.
Half of the current MPAs have at least one patrolling boat in good conditions, or can conduct at least some kind of patrol activities, either alone or with support of additional boats or funding from NGOs. The remaining MPAs do not possess a boat, have a boat in bad condition, or cannot perform adequate patrolling activities due to lack of fuel or personnel among others.

In terms of biological resources monitoring, there are numerous but isolated efforts developed by government agencies, universities, NGOs and volunteers to monitor coral reefs, fish populations, whales and dolphins and turtle nesting sites. An integrated monitoring program, designed to test whether conservation and management goals are being achieved, is currently lacking. Such a monitoring program should include an evaluation of biological resources, especially those related to the conservation goals in each MPA, and an evaluation of management activities being undertaken.

\section{LEGAL GAPS}

The boundaries of many MPAs are poorly defined (especially wetlands down to $6 \mathrm{~m}$ depth), boundary delimitation is ambiguous (Manuel Antonio NP case), or limits are difficult to understand in the sea, such as at Cabo Blanco (where $1 \mathrm{~km}$ of marine protected area border the coastline but the coastline is extremely irregular). Boundary coordinates or very clear limits are needed in some case to allow easy interpretation by both users and park rangers.

Only 54\% of MPAs have a public use plan, and only $27 \%$ MPAs have an official management plan. Fortunately, $36 \%$ of MPAs have an elaborated management plan and in other is in process of formalization. One major problem is that sometimes the process takes so long that the management plan, conceived for a five-year planning period, becomes out of date and results no longer useful. Zoning is another important strategy for diminishing user-user conflicts and user-nature conflicts. Currently, 
$50 \%$ of MPAs have a zoning plan. A specific marine zoning methodology for management plans does not yet exist, resulting in unrealistic zoning in the marine area in some MPAs where the ocean is often considered a homogeneous area. For example in Cabo Blanco, the marine area is considered a single zone. The most successful zoning plans have included participation of the users of the marine park. A protocol defining important aspects to consider when defining marine zones is surely needed to guide MPA managers (Salas et al. in prep., E. Salas 2009, pers. comm.).

Current legal frameworks allow changes to the limits of a PA, a process used by some stakeholders to reduce marine areas in exchange of terrestrial areas for infrastructure development, threatening marine ecosystems through barriers to land-sea connectivity. This sort of trade is being discussed in Gandoca-Manzanillo and San Lucas NWR. Powerful economic interests, especially ocean front real-estate developers, can also exert considerable pressure to change categories to a lower protection level. Finally, the formalization processes for management plans and regulations are still extremely slow.

\section{ENVIRONMENTAL ISSUES}

Environmental threats can be divided into human induced and naturally driven, though this division is not clear at times. Among the natural disturbances affecting the marine environments of Costa Rica the most significant have been. (i) the warming events that occur during El Niño-Southern Oscillation (ENSO) periods, impacts on coral reefs of both coasts (Cortés et al. 1984, Jiménez et al. 2001, Guzmán \& Cortés 2007), followed by (ii) coastal uplift on the Caribbean coast due to an earthquake (Cortés et al. 1992), and (iii) changes in relative sea levels due to climate change along the Pacific coast (Lizano 1997). Other natural disturbances that have affected coastal ecosystems include harmful phytoplankton blooms that killed shallow water corals (Guzmán et al. 1990, C. Jiménez 2008, pers. comm.), strong surge that uprooted seagrasses (Cortés 2001), and massive death of the Caribbean black sea urchin Diadema antillarum (Alvarado et al. 2004).

Human activities in coastal and marine environments of Costa Rica are having a significant impact on organisms, environments and ecological processes. Solid and fecal wastes, oil, agrochemicals, PCB's and heavy metals are the main pollutants (Acuña et al. 1998, 2004, Rojas et al. 1998, Spongberg \& Davis 1998, García-Céspedes et al. 2004, Spongberg 2004a, b, c, García et al. 2006). The main impact on coral reefs in the country is terrigenous sedimentation due to deforestation, coastal alteration for infrastructure (main road construction and tourism developments), and inappropriate agricultural practices (Cortés \& Risk 1985, Cortés 1990, Cortés \& Jiménez 2003a, b, Alvarado et al. 2004, 2009). Other sources of anthropogenic impacts on coastal regions are extraction of marine organisms for sale to tourists, fisheries over-exploitation, and marine mammals disturbance by inappropriate touristic activities.

\section{CURRENT INITIATIVES}

The need to increase conservation and management of the marine and coastal resources of Costa Rica is clearly evident, not only for the protection of sensitive environments, critical habitats or vulnerable species, but also to sustain and offer economic services to coastal populations. Based on those arguments, the government of Costa Rica launched a campaign in 2005 to assess the viability of protection of $25 \%$ of the EEZ (Executive decree 31832MINAE). The objective of such a proposal was to assure resilience of regional marine biodiversity and to fulfill international commitments assumed by the country at the $5^{\text {th }}$ IUCN World Parks Congress (Mora et al. 2006) and Convention on Biological Diversity (CBD), which mandated at $\mathrm{CoP} 7$ the conservation of $10 \%$ of each of the world's eco-regions (http://www.cbd.int/marine).

In 1995-1996, Costa Rica completed an initial analysis of conservation needs for proper maintenance of biodiversity (known as 
GRUAS I). The GRUAS I project and technical proposals for land management, aimed to assure the conservation of at least $90 \%$ of Costa Rica's biodiversity (García 1997), using vegetation macrotypes as indicators (Gómez \& Herrera 1986). However, this proposal left out several vegetation macrotypes, plus all marine and freshwater environments (SINAC 2007a).

Ten years after this proposal, the analysis was redone (GRUAS II), this time including all terrestrial, freshwater and marine environments, enabling a better integration of biodiversity conservation in Costa Rica. GRUAS II identified gaps in conservation, or critical sites that are not adequately represented on the current network of protected areas (SINAC 2007a, b). The following gaps were identified: $2833.3 \mathrm{~km}^{2}$ of the terrestrial ecosystems, 44 lakes and reservoirs, $1223 \mathrm{~km}^{2}$ of river systems and their watershed (SINAC 2007a, b), and approximately $19076 \mathrm{~km}^{2}$ of marine and coastal ecosystems $\left(1323 \mathrm{~km}^{2}\right.$ on the Caribbean coast and $17753 \mathrm{~km}^{2}$ on the Pacific coast) (SINAC 2009, Alvarado et al. 2011).

The Inter-Institutional Commission of the Exclusive Economic Zone of Costa Rica was created in 2004. Among other tasks, this Commission led analysis of the viability of conserving $25 \%$ of the EEZ and elaboration of a National Marine Strategy (NMS). This Commission is constituted by the ministries of Environment (MINAET), Transportation (MOPT), the Costa Rican Fisheries and Aquaculture Institute (INCOPESCA), the National Coast Guard Service, the Costa Rican Tourism Institute (ICT), the University of Costa Rica (UCR), the National University (UNA) and four NGOs (The Nature Conservancy, Conservation International, Asociación Marviva, Programa de Restauración de Tortugas Marinas). The NMS is an initiative established in the 2006-2010 National Development Plan of the Government. The mission of the NMS is to promote the conservation and sustainable management of the coastal and marine resources of Costa Rica, by means of integrated management led by the government and promoting involvement of the rest of society (CIZEE 2008).

\section{CONCLUSIONS}

In the last 50 years of conservation, Costa Rica has done much to protect its environment. Thanks to those initiatives, the country possesses arguably the best MPA network, in terms of representation, in the entire region. Conservation started inland, with inclusion of marine areas occurring little by little, but without a good understanding of what was being protected in most cases. With the relatively strict protection of coastal areas now achieved, most marine resources should not suffer from overexploitation and exist through the long term.

The gradual degradation of the coasts, in addition to overfishing and other extractive activities outside MPAs, has caused a great current pressure on resources inside MPAs. This has resulted in serious conflicts with inhabitants living adjacent to MPAs, and among the authorities that administrate fisheries. Exacerbating this problem is that many of the current MPAs were created without any real consultation to nearby communities. This has resulted in a latent resentment against the administration authorities.

The presence of no-take MPAs has been fundamental to long-term maintenance of the high biodiversity that Costa Rica possesses. However, this model should be complemented with the creation of new protected areas that may allow regulated recreational and extractive activities. In view of these needs the two new categories (Marine Reserve and Marine Management Areas) arise in response to a more balanced model. In fact, all coastal and marine areas should be regulated.

Nevertheless, for both models of management (take and no-take) to work well, it is urgent to improve institutional coordination, improve personnel training, provide greater economic resources and trained personnel to MPAs, and to regulate activities in nearby watersheds. Following 50 years of conservation practice, Costa Rica is still learning how to do it better. Recent increases in research and in regional cooperation (e.g. Marine Conservation Seascape of the Eastern Tropical Pacific) are 
new ways to take care and maintain a healthy network of marine protected areas.

\section{ACKNOWLEDGMENTS}

We would like to thank E. Arias for facilitating the GIS data base of the current system of Protected Areas of Costa Rica, R. Mora for his help on the elaboration on the map and corrections on the original data base, and $\mathrm{M}$. Chavez for the elaboration of the figures. JJAB thanks CONICIT, MICIT and CONACYT; JC appreciates the support of the Universidad de Costa Rica and ES that of MarViva. We appreciate the comments made by M. Kappelle, A. Morales and two anonymous reviewers that improved this paper.

\section{RESUMEN}

Con $51100 \mathrm{~km}^{2}$ de área terrestre y $589000 \mathrm{~km}^{2} \mathrm{de}$ aguas jurisdiccionales, Costa Rica es considerado uno de los países con mayor biodiversidad. Posee aproximadamente $3.5 \%$ de las especies marinas del mundo. En las últimas cuatro décadas, Costa Rica ha dedicado un esfuerzo significativo para la creación de Áreas Protegidas (AP), principalmente terrestres. Aquí presentamos un diagnóstico de la situación actual de las Áreas Marinas Protegidas (AMP) en Costa Rica, a través de un análisis histórico, su distribución, cobertura y categorías de manejo. Costa Rica posee 166 áreas protegidas que cubren $50 \%$ de la línea de costa, de las cuales 20 son AMP clasificadas como Parque Nacionales (90.6\%), Refugios de Vida Silvestre (6.6\%), humedales (1.5\%), Reservas Biológicas (1\%) y una Reserva Natural Absoluta (0.3\%). De acuerdo a los criterios de la UICN, $93.7 \%$ corresponden a la categoría II, $5 \%$ a la IV y $1.3 \%$ a la I. El área marina protegida es de $5296.5 \mathrm{~km}^{2}$, correspondiendo al $17.5 \%$ de las aguas territoriales y al $0.9 \%$ de la Zona Económica Exclusiva. La distancia promedio entre AMP es de $22.4 \mathrm{~km}$ en el Pacífico y $32.9 \mathrm{~km}$ en el Caribe. El tamaño medio está cercano a los $54 \mathrm{~km}^{2}$. Las amenazas principales son la falta de coordinación entre agencias gubernamentales, recursos económicos limitados, control y patrullaje restringido, pobre manejo de cuencas y una acelerada alteración costera.

Palabras clave: categoría de manejo, Zona Económica Exclusiva, conservación marina, tamaño, distancia.

\section{REFERENCES}

Acuña, J.A., V. García \& J. Mondragón. 1998. Comparación de algunos aspectos físico-químicos y calidad sanitaria del Estero de Puntarenas, Costa Rica. Rev. Biol. Trop. 46: 1-10.

Acuña-González, J., J.A. Vargas-Zamora, E. Gómez-Ramírez \& J. García-Céspedes. 2004. Hidrocarburos de petróleo, disueltos y dispersos, en cuatro ambientes costeros de Costa Rica. Rev. Biol. Trop. 52: 43-50.

Alvarado, J.J., J. Cortés \& E. Salas. 2004. Population densities of Diadema antillarum Philippi at Cahuita National Park (1977-2003), Costa Rica. Caribb. J. Sci. 40: 257-259.

Alvarado, J.J., J. Cortes \& C. Fernández. 2009. Water quality conditions on coral reefs at the Marino Ballena National Park, Pacific Costa Rica. Bull. Mar. Sci. 84: 137-152.

Alvarado, J.J., B. Herrera, L. Corrales, J. Asch \& P. Paaby. 2011. Identificación de las prioridades de conservación de la biodiversidad marina y costera en Costa Rica. Rev. Biol. Trop. 59: 829-842.

Bohrmann, G., K. Heeschen, C. Jung, W. Weinrebe, B. Baranov, B. Cailleau, R. Heath, V. Huhnerbach, M. Hort, D. Masson \& I. Trummer. 2002. Widespread fluid expulsion along the seafloor of the Costa Rica convergent margin. Terra Nova 14: 69-79.

Chape, S., J. Harrison, M. Spalding \& I. Lysenko. 2005. Measuring the extent and effectiveness of protected areas as an indicator for meeting global biodiversity targets. Phil. Trans. R. Soc. B. 360: 443-455.

Coates, A.G., J.B.C. Jackson, L.S. Collins, T.M. Cronin, H.J. Dowset, L.M. Bybell, P. Jung \& J.A. Obando. 1992. Closure of the Isthmus of Panama: the nearshore marine records of Costa Rica and western Panama. Geol. Soc. Am. Bull. 104: 814-828.

Cortés, J. 1990. The coral reefs of Golfo Dulce, Costa Rica: distribution and community structure. Atoll Res. Bull. 344: 1-37.

Cortés, J. 2001. Requiem for an eastern Pacific seagrass bed, Bahía Culebra, Costa Rica. Rev. Biol. Trop. 49: 273-278.

Cortés, J. 2007. Coastal morphology and coral reefs, p. 185-200. In J. Bundschuh \& G.E. Alvarado (eds.). 
Central America: geology, resources, and hazards Vol. 1. Taylor \& Francis, United Kingdom.

Cortés, J. \& C. Jiménez. 2003a. Past, present and future of the coral reefs of the Caribbean coast of Costa Rica, p. 223-239. In J. Cortés (ed.). Latin American coral reefs. Elsevier, Amsterdam, The Netherlands.

Cortés, J. \& C. Jiménez. 2003b. Corals and coral reefs of the Pacific of Costa Rica: history, research and status, p. 361-385. In J. Cortés (ed.). Latin American coral reefs. Elsevier, Amsterdam, The Netherlands.

Cortés, J. \& M.J. Risk. 1985. A reef under siltation stress: Cahuita, Costa Rica. Bull. Mar. Sci. 36: 339-356.

Cortés, J. \& I.S. Wehrtmann. 2009. Diversity of marine habitats of the Caribbean and Pacific of Costa Rica, p. 1-45. In I.S. Wehrtmann \& J. Cortés (eds.). Marine biodiversity of Costa Rica, Central America. Monographiae Biologicae 86. Springer, Berlin, Germany.

Cortés, J., M.M. Murillo, H.M. Guzmán \& J. Acuña. 1984. Pérdida de zooxantelas y muerte de corales y otros organismos arrecifales en el Caribe y Pacífico de Costa Rica. Rev. Biol. Trop. 32: 227-232.

Cortés, J., R. Soto, C. Jiménez \& A. Astorga. 1992. Earthquake associated mortality of intertidal and coral reef organisms. Proc. $7^{\text {th }}$ Int. Coral Reef Sym.1: 235-240.

CIZEE (Comisión Interinstitucional de la Zona Económica). 2008. Estrategia nacional para la gestión integral de los recursos marinos y costeros de Costa Rica. Comisión Interinstitucional de la Zona Económica Exclusiva de Costa Rica, San José, Costa Rica.

D’Croz, L. \& D.R. Robertson. 1997. Coastal oceanographic conditions affecting coral reefs on both sides of the Isthmus of Panama. Proc. $8^{\text {th }}$ Int. Coral Reef Sym. 2: 2053-2058.

Dudley, N. 2008. Guidelines for applying protected area management categories. IUCN, Gland, Switzerland.

Edgar, G.F., G.R. Russ \& R.C. Babcock. 2007. Marine protected areas, p. 533-555. In S.D. Connell \& B.M. Gillanders (eds.). Marine Ecology. Oxford University, Melbourne, Australia.

García, R. 1997. Biología de la conservación y áreas silvestres protegidas: situación actual y perspectivas en Costa Rica. Editorial INBio, Heredia, Costa Rica.

García, V., J. Acuña-González, J.A. Vargas-Zamora \& J. García-Céspedes. 2006. Calidad bacteriológica y desechos sólidos en cinco ambientes costeros de Costa Rica. Rev. Biol. Trop. 54: 35-48.

García-Céspedes, J., J.A. Acuña-González \& J.A. VargasZamora. 2004. Metales traza en sedimentos de cuatro ambientes costeros de Costa Rica. Rev. Biol. Trop. 52: 51-60.

GASP (Gerencia de Áreas Silvestres Protegidas). 2006. Informe nacional sobre el sistema de áreas silvestres protegidas de Costa Rica. SINAC, MINAE, San José, Costa Rica.

Gómez, L.D. \& W. Herrera. 1986. Vegetación y clima de Costa Rica. EUNED, San José, Costa Rica.

Guarderas, A.P., S.D. Hacker \& J. Lubchenco. 2008. Current status of marine protected areas in Latin America and the Caribbean. Conservat. Biol. 22: 1630-1640.

Guzmán, H.M. \& J. Cortés. 2007. Reef recovery 20-yr after the 1982-83 El Niño massive mortality. Mar. Biol. 151: 401-411.

Guzmán, H.M., J. Cortés, P.W. Glynn \& R.H. Richmond. 1990. Coral mortality associated with dynoflagellate blooms in the eastern Pacific (Costa Rica and Panama). Mar. Ecol. Prog. Ser. 60: 299-303.

Halpern, B.S. 2003. The impact of marine reserves: do reserves work and does reserve sizes matter? Ecol. Appl. 13: S117-S137.

Hoyt, E. 2005. Marine protected areas for whales, dolphins and porpoises: A world handbook for cetacean habitat conservation. Earthscan, London, United Kingdom.

Jackson, J.B.C. \& L. D'Croz. 1997. The ocean divided, p. 38-70. In A.G. Coates (ed.). Central America: a cultural and natural history. Yale University, New Haven, USA.

Jiménez, C., J. Cortés, A. León \& E. Ruiz. 2001. Coral bleaching and mortality associated with El Niño $1997 / 98$ event in an upwelling environment in the

SINAC (Sistema Nacional de Áreas de Conservación). 2009. GRUAS II: Propuesta de ordenamiento territorial para la conservación de la biodiversidad en Costa Rica. Vol. IIII. Análisis de vacíos en la representatividad e integridad de la biodiversidad de los sistemas marinos y costeros. San José, Costa Rica. 
Spongberg, A.L. 2004a. PCB Contamination in surface sediments in the coastal waters of Costa Rica. Rev. Biol. Trop. 52 1-10.

Spongberg, A.L. 2004b. PCB concentrations in sediments from the Gulf of Nicoya estuary, Pacific coast of Costa Rica. Rev. Biol. Trop. 52: 11-22.

Spongberg, A.L. 2004c. PCB contamination in marine sediments from Golfo Dulce, Pacific coast of Costa Rica. Rev. Biol. Trop. 52: 23-32.
Spongberg, A. \& P. Davis. 1998. Organochlorinated pesticide contaminants in Golfo Dulce, Costa Rica. Rev. Biol. Trop. 46: 111-124.

Wehrtmann, I.S., J. Cortés \& S. Echeverría-Sáenz. 2009. Marine biodiversity of Costa Rica: perspectives and conclusions, p. 521-533. In I.S. Wehrtmann \& J. Cortés (eds.). Marine biodiversity of Costa Rica, Central America. Monographiae Biologicae 86. Springer, Berlin, Germany.

\section{Nota}

Durante la edición final de esta investigación para su publicación, el Gobierno de Costa Rica decretó (Nº 36452-MINAET; 3 marzo 2011) la creación del Área Marina de Manejo Montes Submarinos. Esta área marina protegida está compuesta por $9640 \mathrm{~km}^{2}$, y se localiza en el Océano Pacífico entre las coordenadas $6^{\circ} 08^{\prime} \mathrm{N}-87^{\circ} 00^{\prime} \mathrm{W}, 5^{\circ} 44^{\prime} \mathrm{N}-86^{\circ} 26^{\prime} \mathrm{W}, 4^{\circ} 47^{\prime} \mathrm{N}-87^{\circ} 17^{\prime} \mathrm{W}$ y $4^{\circ} 58^{\prime} \mathrm{N}-88^{\circ} 00^{\prime} \mathrm{W}$. La administración de la misma está bajo el Área de Conservación Marina Isla del Coco (ACMIC), ya que rodea el actual Parque Nacional Isla del Coco (PNIC). Entre otras razones, es creada para ayudar en la regulación de la actividad pesquera que se da alrededor del PNIC, un área marina protegida de gran importancia en el Corredor de Conservación Marina del Pacífico Oriental.

Note: During the final edition of this paper, the Government of Costa Rica decreted $\left(\mathrm{N}^{\circ}\right.$ 36452-MINAET; 3 March 2011) the creation of the Marine Management Area Submarine Mounts. This marine protected area is $9640 \mathrm{~km}^{2}$, and is located in the Pacific Ocean between the coordinates $6^{\circ} 08^{\prime} \mathrm{N}-87^{\circ} 00^{\prime} \mathrm{W}, 5^{\circ} 44^{\prime} \mathrm{N}-86^{\circ} 26^{\prime} \mathrm{W}, 4^{\circ} 47^{\prime} \mathrm{N}-87^{\circ} 17^{\prime} \mathrm{W}$ y $4^{\circ} 58^{\prime} \mathrm{N}-88^{\circ} 00^{\prime} \mathrm{W}$. Its administration is under the Isla de Coco Marine Conservation Area, since it surrounds the current Isla del Coco National Park. Among other reasons, the creation of this area intends to serve as a buffer to regulate fishing activity around Isla del Coco National Park, a very important marine protected area in the Eastern Pacific Marine Conservation Corridor. 